\title{
Isolation of Thermophilic Enzyme-producing Parageobacillus Bacteria from Chipped Woody Waste
}

\author{
Olesya Yunitsyna, ${ }^{\mathrm{a}}$ Igor Sinelnikov, ${ }^{\mathrm{a}}$ Oksana Kisil, ${ }^{\mathrm{a}}$ Ksenia Bolotova, ${ }^{\mathrm{a}}$ Andrey Aksenov, ${ }^{\mathrm{a}}$ \\ and Galina Simonsen ${ }^{b}$
}

The morphological and biochemical properties were investigated for 18 types of thermophilic bacteria isolated from a woody-chip pile at a wood processing plant in Northern Russia. Genetic fingerprinting and 16S rRNA identification were used to divide the investigated microorganisms into groups according to their genetic affiliation. It was found that the isolated bacteria belonged to a minimally studied genus of Parageobacillus and exhibited optimum temperature and $\mathrm{pH}$ in the ranges of 57 to $60^{\circ} \mathrm{C}$ and 7.0 to 8.5 , respectively. The amylase activity was determined for all of the 18 isolated strains. Catalytic properties of the bacteria-produced xylanases were evaluated with respect to their activity towards xylan and xylan-containing carbon substrates. Biotechnological potential of the two most promising bacterial strains (Parageobacillus caldoxylosilyticus and Parageobacillus thermoglucosidasius) and their possible use in xylanase production was evaluated. The results showed that bacteria present in the chipped woody waste is an important source of thermoalkalophilic enzymes.

Keywords: Parageobacillus caldoxylosilyticus; Parageobacillus thermoglucosidasius; Woody-chip pile; Thermophiles; Amylases; Xylanases

Contact information: a: Department of Biology, Ecology and Biotechnology, Northern (Arctic) Federal University, Arkhangelsk, Russia; $b$ : Department of Chemical Engineering, Norwegian University of Science and Technology (NTNU), Trondheim, Norway; *Corresponding author: galinanorge@gmail.com

\section{INTRODUCTION}

Modern industrial biotechnology demands the development of high-performance biocatalysts, or enzymes, applicable in a variety of industrial operations (Choi et al. 2015; Jemli et al. 2016; Blamey et al. 2017; Madhavan et al. 2017). Enzyme-assisted processes are of great importance in waste minimization and recycling due to the high efficiency of enzymes, their low consumption, and selectivity in removal of unwanted compounds. Cellulases constitute a well-known class of enzymes capable of hydrolyzing $1,4-\beta-D-$ glucosidic linkages in cellulose, which is a polymer available globally for bioconversion into numerous products. Cellulases have a long history of applications, including processing of wood biomass, textile and laundry, food, and bioethanol production (Coughlan 1985; Hardiman et al. 2010; Behera et al. 2017). In addition to cellulases, other enzymes capable of hydrolyzing non-cellulosic polysaccharides, such as amylases and xylanases (Hu et al. 2015), are continuously gaining importance in the global market of bioconversion and recycling processes (Pandey et al. 2000; Saxena and Singh Chauhan 2016). Amylases is a group of enzymes capable of hydrolyzing glycosidic bonds in starch, namely, $\alpha$-amylase, $\beta$-amylase, and glucoamylase. The amylases are traditionally used at elevated temperatures and can be derived from a variety of plant and microbial sources (Gopinath et al. 2017). They are commonly utilized in the processing of raw grain materials (Nigam and Singh 1995), removal of starch present in waste paper and paperboard (Saxena and Singh Chauhan 2016), and paper recycling (Raul et al. 2014). The hydrolysis of xylan, 
a major component of hemicelluloses, can be achieved by xylanases or xylanase mixtures containing endo- $\beta-1,4$-xylanases and $\beta$-D-xylosidases (Polizeli et al. 2005). Xylanases have been used by the industry since the early 1990's. They are recognized for their catalytic effects in improving efficiency of the existing pulp bleaching processes (Viikari et al. 1994) and bioconversion of agricultural waste into fuel and chemicals (Nigam and Pandey 2009). One of the main challenges in xylanase production from bacterial sources is the high cost of the xylanase inducer, pure xylan (Alves et al. 2016). Waste materials from wood processing plants, as well as other lignocellulosic sources, can serve as alternative carbon substrates for the production of xylanases. The use of such substrates can reduce the cost of the entire process. At present, researchers are looking for novel bacterial strains capable of assimilating lignocellulosic waste as a cost-effective carbon source for the production of xylanases (Bhalla et al. 2015).

One of the important features of microbial enzymes is that they exhibit substrate selectivity and stability under abnormal conditions, mainly high temperatures and $\mathrm{pH}$ extremes. Based on their stability, certain enzymes can be categorized as thermophilic, acidophilic, or alkalophilic. These properties make them valuable contributors to multiple industrial processes. One example is the application of thermoalkalophilic enzymes in pulp and paper production and paper recycling, where both the temperatures and $\mathrm{pH}$ often rise above $50{ }^{\circ} \mathrm{C}$ and 8 , respectively. The thermoacidophilic enzymes can contribute to enhancing mass transfer and reducing substrate viscosity during hydrolysis of raw plant materials in industrial processes (Cai et al. 2011).

Microbial enzymes can be produced by different microorganisms, both bacterial and fungal species. Although fungal species are significant producers of thermostable enzymes, the obtained enzymes often lack stability at high temperatures and $\mathrm{pH}$ and do not qualify for use in certain biotechnological applications (Kumar et al. 2013). Therefore, the search for new bacteria that are capable of synthesizing stable enzymes is highly relevant. The enzyme-producing bacteria can be isolated from a variety of waste sources, one of which is the chipped woody waste produced in abundance by wood processing plants. The composition, and therefore bacterial presence in such wastes, will vary depending on the season, storage, mixing conditions, type of wood waste, and many other factors. This variety gives endless possibilities for discovering and extracting new bacterial species with unique properties that have not been previously reported.

In this work, several types of bacteria have been isolated from samples of a chipped woody waste pile located at a wood processing plant in Northern Russia. The bacteria are identified and characterized with respect to their amylolytic and xylanolytic properties. Two bacterial strains, $P$. caldoxylosilyticus and $P$. thermoglucosidasius, were chosen for detailed study due to their promising ability to produce xylanolytic enzymes. A selection of carbon substrates was used to evaluate the bacterial performance in terms of xylanase activity and xylanase production in industrial conditions.

\section{EXPERIMENTAL}

\section{Materials}

Study site, sampling, and bacteria isolation

Samples of wood chips were collected from a woody chip pile at a timber mill named Solombalales located in the city of Arkhangelsk in Northern Russia (64 $35^{\prime} 19^{\prime \prime} \mathrm{N}$, $40^{\circ} 33$ '20"E) (Fig. 1A). The sampling was carried out at the following depths: pile surface (bark), 2 to $10 \mathrm{~cm}, 10$ to $30 \mathrm{~cm}$, and 80 to $100 \mathrm{~cm}$ (Fig. 1B). The pile was semi-anaerobic 
at each sampling point due to periodic mixing. The samples were placed into sterile plastic containers $(500 \mathrm{~mL})$ and transported to the laboratory at ambient temperature.

Once the samples arrived, they were sealed separately into 100-mL airtight bottles containing $0.1 \%$ peptone solution and kept at $65{ }^{\circ} \mathrm{C}$ for five days stirring at $150 \mathrm{rpm}$. The primary screening of the bacteria was carried out in a minimal medium (MM) containing potassium hydrogen phosphate trihydrate $\left(\mathrm{K}_{2} \mathrm{HPO}_{4} \cdot 3 \mathrm{H}_{2} \mathrm{O} ; 5.24 \mathrm{~g} / \mathrm{L}\right)$, magnesium sulfate heptahydrate $\left(\mathrm{MgSO}_{4} \cdot 7 \mathrm{H}_{2} \mathrm{O} ; 1 \mathrm{~g} / \mathrm{L}\right)$, potassium chloride $(\mathrm{KCl} ; 0.2 \mathrm{~g} / \mathrm{L})$, iron(II) sulfate $\left(\mathrm{FeSO}_{4} ; 11.4 \mathrm{mg} / \mathrm{L}\right)$, xylan $(1 \%)$, peptone $(0.5 \%)$, yeast extract $(0.1 \%)$, agar $(1.5 \%)$, and trace element solution $(1 \mathrm{~mL})$. The system was incubated for $24 \mathrm{~h}$ at $60{ }^{\circ} \mathrm{C}$ (Valladares Juárez et al. 2009). Cultures showing different colony morphology were separated and further purified by streaking on the same medium at least three more times. The purified bacteria cultures were stored in glycerol stock $(15 \%)$ at $-80{ }^{\circ} \mathrm{C}$.

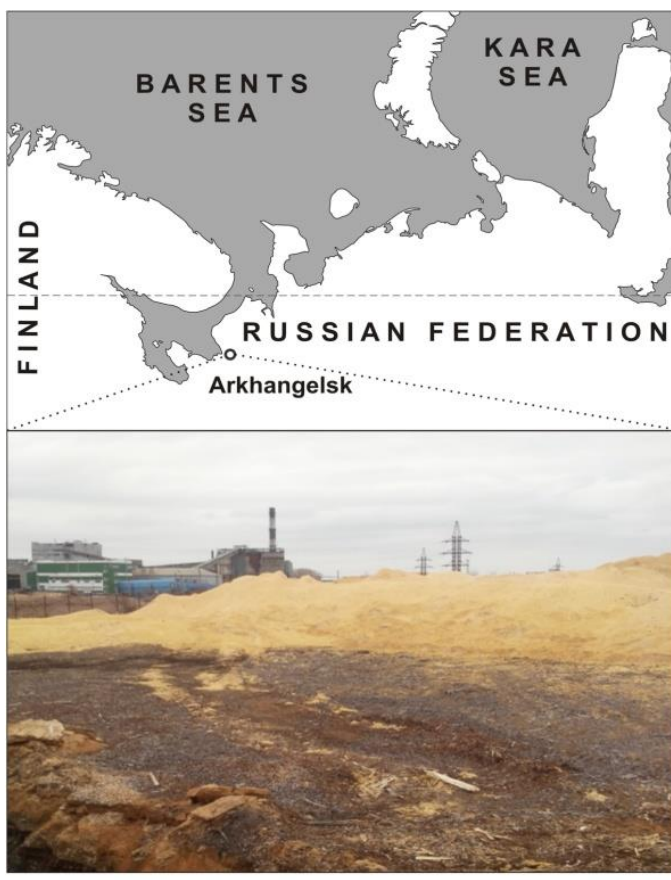

A

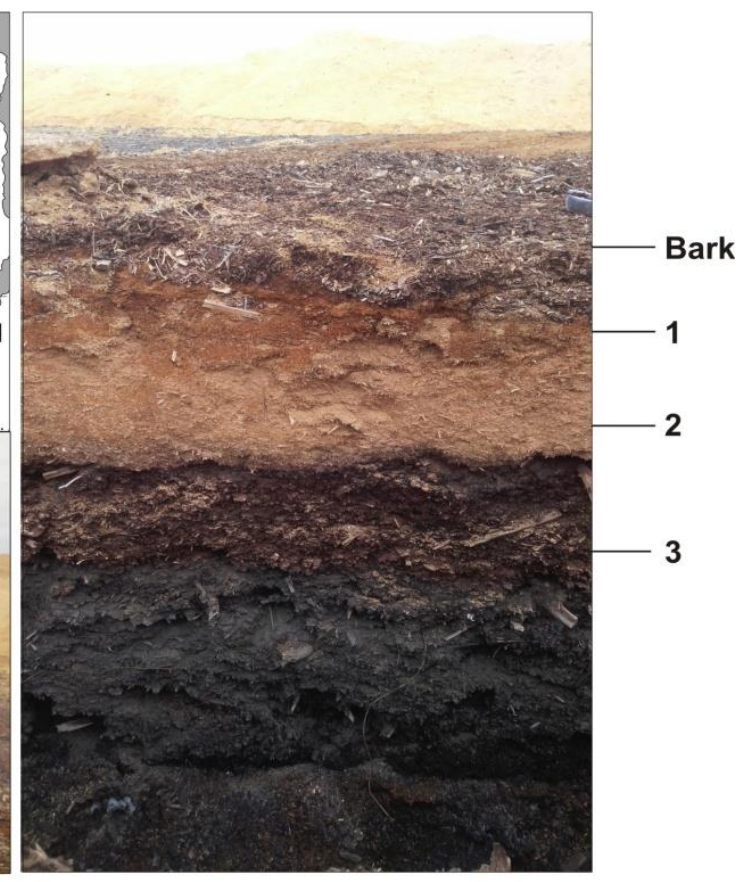

B

Fig. 1. Woody-chip pile located at the timber mill Solombalalets (A - study site) and sampling points (B)

\section{Methods}

Morphological and biochemical characterization of the isolated bacterial strains

The morphology and visual appearance of the bacterial strains was evaluated by scanning electron microscopy (SEM) using a SIGMA VP microscope (Carl Zeiss, Oberkochen, Germany) at an accelerating voltage of $10 \mathrm{kV}$ with an in-lens detector. The strains were cultivated for $24 \mathrm{~h}$ at $55^{\circ} \mathrm{C}$ on a Luria-Bertani (LB) medium. A piece of the medium was separated and freeze-dried using a FreeZone 2.5 L Benchtop Freeze Dry System (Labconco). The dried samples were then used for the microscopic analysis. The spore formation was monitored with a Primo Star (Carl Zeiss, Oberkochen, Germany) optical microscope. Single bacterial colonies were observed on agar plates at different incubation periods.

The Gram type of the isolated strains was determined using a Gram coloring kit in accordance with the manufacturer's instructions (JSC "Ecolab", Moscow, Russia). 
The utilization of carbon compounds was determined using differential diagnostic media of Hiss (Sinelnikov et al. 2017) including one of the carbon sources (glucose, lactose, maltose, mannitol, sucrose, or sorbitol). A positive result was indicated by a change in medium color after cultivation of the isolates for 18 to $24 \mathrm{~h}$ at $60{ }^{\circ} \mathrm{C}$.

\section{Polymerase chain reaction (PCR) fingerprinting with (GTG)5 primer}

The repetitive sequence-based (GTG)5-PCR fingerprinting methods were only used for preliminary genotypic characterization of bacteria to avoid high costs associated with comparative characterization of the species. The sequence (5'-GTGGTGGTGGTGGTG-3') was used as a primer (Rasschaert et al. 2005). The PCR reaction was activated in a $25 \mu \mathrm{L}$ solution containing 25 pmol of primer, $2.5 \mu \mathrm{L} 10 \times$ PCR buffer $(10$ $\mathrm{mM}$ Tris, $50 \mathrm{mM} \mathrm{KCl}, \mathrm{pH} 8.3$ ), $200 \mu \mathrm{M}$ of deoxynucleotide (dNTPS), $25 \mathrm{mM}$ of magnesium chloride $\left(\mathrm{MgCl}_{2}\right), 1 \mathrm{U}$ of Taq DNA polymerase, and $4 \mu \mathrm{L}$ of template DNA. The cycling conditions were the same as for the (GTG)5. The initial denaturation was performed at $95{ }^{\circ} \mathrm{C}$ for $5 \mathrm{~min}$, followed by 35 cycles of denaturation at $94{ }^{\circ} \mathrm{C}$ for $1 \mathrm{~min}$, annealing at $50{ }^{\circ} \mathrm{C}$ for $1 \mathrm{~min}$, extension at $72{ }^{\circ} \mathrm{C}$ for $1 \mathrm{~min}$, and a final extension at $72{ }^{\circ} \mathrm{C}$ for $8 \mathrm{~min}$. Approximately $8 \mu \mathrm{L}$ of the PCR product was loaded into $1 \%$ agarose gel and followed by the fingerprinting analysis (Kathleen et al. 2014).

\section{S rRNA gene sequence analysis}

Single bacterial colonies were picked out and introduced into a pre-warmed LB medium. A total of $2 \mu \mathrm{L}$ was transferred into a PCR tube after cultures reached the exponential phase. The measured sample absorbance at a wavelength of $600 \mathrm{~nm}$ (OD600) was between 0.5 and 1. The PCR mix containing 1.25 units of DreamTaq DNA polymerase (Alkor-Bio, Saint Petersburg, Russia), $10 \times$ of DreamTaq buffer (Alkor-Bio, Saint Petersburg, Russia), $100 \mu \mathrm{M}$ of dNTPs (Alkor-Bio, Saint Petersburg, Russia), $0.2 \mu \mathrm{M}$ of both $27 \mathrm{~F}$ and $1492 \mathrm{R}$ primers, and Milli-Q water was added to a total volume of $50 \mu \mathrm{L}$ (Daas et al. 2016). The PCR conditions were as follows: initial denaturation at $95{ }^{\circ} \mathrm{C}$ for $10 \mathrm{~min}, 95$ ${ }^{\circ} \mathrm{C}$ for $30 \mathrm{~s}, 56{ }^{\circ} \mathrm{C}$ for $30 \mathrm{~s}$, and $72{ }^{\circ} \mathrm{C}$ for $1.5 \mathrm{~min}$ with the final extension at $72{ }^{\circ} \mathrm{C}$. The PCR amplification was performed with a T100 ${ }^{\mathrm{TM}}$ Thermal Cycler (Bio-Rad, Hercules, USA). The amplified products were purified, and the sequence of the 16S rRNA gene was determined by DNA sequencing with the Sanger method on a DNA sequencer NANOFOR-

05 (Synthol, Moscow, Russia). The sequence database comparison was performed using the BLAST software through the National Center for Biotechnology Information (NCBI, Bethesda, Maryland) website.

\section{Plate test for amylase activity}

The isolated bacterial strains were screened for amylase activity by a starch hydrolysis test. The purified strains were grown on the agar MM medium containing $1 \%$ soluble starch at $60{ }^{\circ} \mathrm{C}$ for $24 \mathrm{~h}$. The presence of amylase activity was confirmed by the appearance of clear halos around colonies after staining with Lugol's iodine (Teodoro and Martins 2000).

\section{Xylanase production and assay of xylanase activity}

The xylanase activity was determined by testing extracts of the isolated bacterial strains. The cells were cultivated in the liquid MM medium with $1 \%$ oat spelt xylan at 60 ${ }^{\circ} \mathrm{C}$ for $24 \mathrm{~h}$. The culture fluids were centrifuged at $4200 \mathrm{rpm}$ for $20 \mathrm{~min}$ at $4{ }^{\circ} \mathrm{C}$. The xylanase activity was measured using the Nelson-Somogyi method (Sinitsyna et al. 2003). The reaction mixture contained $40 \mu \mathrm{L}$ of appropriately diluted culture filtrate and $160 \mu \mathrm{L}$ 
of the $1 \%$ xylan solution that was prepared in the acetate buffer $(0.05 \mathrm{M}, \mathrm{pH} 5.0)$ and then incubated for $10 \mathrm{~min}$ at $50{ }^{\circ} \mathrm{C}$. After incubation, the reaction was stopped by the addition of $200 \mu \mathrm{L}$ of Somogyi reagent and heated for $40 \mathrm{~min}$ in a hot water bath. After cooling, $200 \mu \mathrm{L}$ of Nelson reagent (Helicon, Saint Petersburg, Russia) was added. After 15 min, $400 \mu \mathrm{L}$ of acetone and $1000 \mu \mathrm{L}$ of Milli-Q water was added. The resulting reducing sugars were measured spectrophotometrically (IMPLEN, München, Germany) at $610 \mathrm{~nm}$ and expressed as xylose equivalent. Xylose was taken as a standard (Sinelnikov et al. 2017). One-unit enzyme activity was defined as the amount of enzyme required to produce 1 mmol reducing sugar per min under standard assay conditions.

\section{Effect of substrate specificity on xylanase activity}

Three different carbon substrates, birch chips, brewers' spent grain, and oat spelt xylan, were used to test the effect of different carbon sources on the xylanase activity. The bacteria were cultivated in a liquid medium containing $\mathrm{K}_{2} \mathrm{HPO}_{4}(2.5 \mathrm{~g} / \mathrm{L}), \mathrm{KH}_{2} \mathrm{PO}_{4}(0.5$ $\mathrm{g} / \mathrm{L}), \mathrm{CaCl}_{2}(0.2 \mathrm{~g} / \mathrm{L}),(\mathrm{NH} 4)_{2} \mathrm{SO}_{4}(0.5 \mathrm{~g} / \mathrm{L})$, peptone $(0.5 \%)$, yeast extract $(0.2 \%)$, glucose $(20 \mathrm{~g} / \mathrm{L})$, and $1 \%(\mathrm{w} / \mathrm{v})$ of one of the carbon substrates (Alves et al. 2016). The cell culture fluids were used as the enzyme source. The xylanase activity was measured using the Nelson-Somogyi method.

\section{Optimal conditions for bacterial growth}

The optimal temperature range for bacterial growth was determined after incubation in the LB liquid medium at a temperature range from $55^{\circ} \mathrm{C}$ to $70{ }^{\circ} \mathrm{C}$. The $\mathrm{pH}$ influence on bacterial growth was tested after incubation in the LB liquid medium $\mathrm{pH}$, which ranged from 5 to 11. The optimum growth was established by measuring an increase in turbidity at the wavelength of $600 \mathrm{~nm}$. The turbidity tests were performed using a NanoPhotometer NP80 spectrophotometer (IMPLEN, München, Germany).

\section{RESULTS AND DISCUSSION}

Large quantities of chipped woody waste deposits are produced and stored in Northern parts of Russia due to a large and ever-growing timber industry. The deposits are affected by relatively high temperatures in the deep layers during summer periods, which makes them a suitable and unique place for the development of thermophilic microorganisms. The research focusing on the isolation, identification, and characterization of enzymes produced by thermophilic microorganisms typically includes a preliminary study of the hydrothermal sources to find out whether or not they contain any unique microorganisms. Their isolation from self-heating wood waste deposits inherently introduces a high potential of obtaining industrially important enzymes applicable in the bioconversion of plant materials. Larsen and McCartney (2000) reported that composting deposits of different types of bark and wood chips could contain as much as 20 to $35 \%$ of free air space throughout the composting process. This ensures easy access of oxygen to the upper layers of the pile and allows for growth of the thermophilic microorganisms (Handelsman 2004; Streit et al. 2004).

In the current work, a total of 18 bacterial strains were isolated from a woody-chip pile sample during a screening process. The morphological characterization was performed based on visual appearances of the bacterial colonies as well as SEM images of the separate cells. The isolated strains differed slightly according to their morphological features. It was observed that smooth and round colonies of beige and light-brown colors were formed on 
a solid medium. Examples of bacterial colonies grown for $24 \mathrm{~h}$ from strains 13 to 16 are presented in Fig. 2.

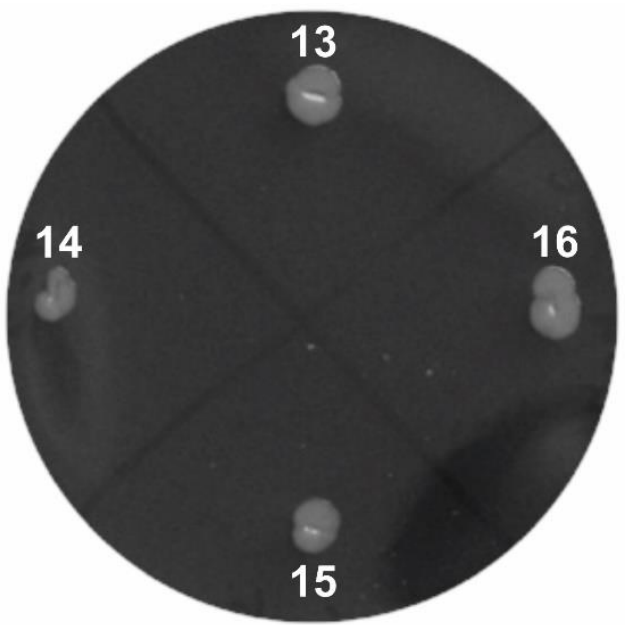

Fig. 2. A photograph of bacterial colonies on agar medium (strains 13 to 16)

All of the bacterial isolates were moderately thermophilic, aerobic or facultative anaerobic, motile, and Gram-positive rods. The isolates were observed as single cells, 4to 5- $\mu \mathrm{m}$-long and 1.0- to 1.5- $\mu \mathrm{m}$-wide (Figs. $3 \mathrm{~A}$ and 3B). Figures $3 \mathrm{~A}$ and $3 \mathrm{~B}$ are SEM images that show a fully-grown bacterial colony (after $24 \mathrm{~h}$ ) under different magnifications. The cells were arranged into long chains and showed signs of spore formation.
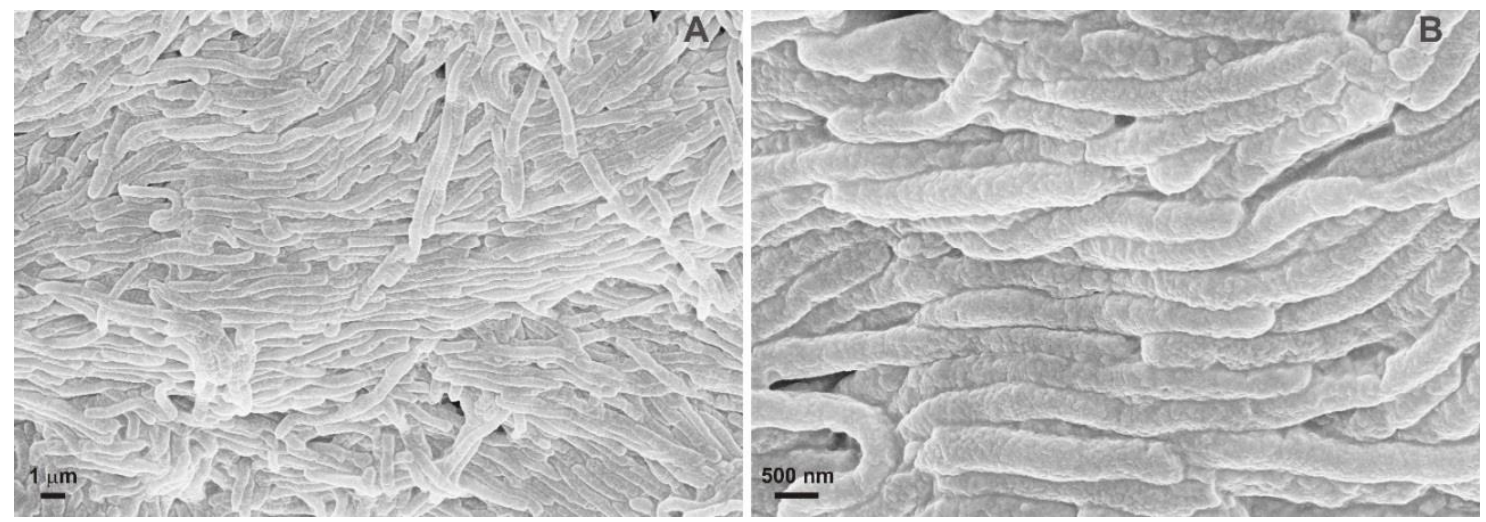

Fig. 3. SEM images of bacteria isolated from woody-chip pile

The biochemical characterization tests were performed on the Hiss's media and revealed no noticeable differences in the metabolism of the studied bacterial strains. All of the isolates showed high utilization of various carbon sources with varying ability to utilize sucrose, glucose, and maltose (Table 1). The broadest spectrum of carbohydrates was utilized by bacterial strains isolated from the bark layer (strains 13 to 18) and from relatively deep layers of the woody-chip pile (strains 10 to 12).

Identification techniques based on phenotype usually show discrepancies between phenotypic and genotypic identifications (Renneberg et al. 1995). It is known that gene sequencing using gold as a standard provides the most accurate genotypic identification of species. However, gene-sequencing methods may be economically unviable in analyses of large amounts of isolates. DNA fingerprinting is based on a PCR amplification of genomic 
elements between interspersed repeated DNA sequences. This results in a specific DNA band pattern after (GTG)5-PCR fingerprinting.

Table 1. Summary of Carbohydrate Utilization by Isolated Bacterial Strains

\begin{tabular}{|c|c|c|c|c|c|c|c|}
\hline Strain & Glucose & Lactose & Sucrose & Sorbitol & Maltose & Mannitol & Xylose \\
\hline 1 & + & + & - & + & + & + & + \\
\hline 2 & + & + & - & + & + & \pm & + \\
\hline 3 & - & + & - & + & - & \pm & + \\
\hline 4 & + & \pm & - & + & - & + & + \\
\hline 5 & - & + & \pm & + & + & \pm & + \\
\hline 6 & + & \pm & - & + & + & \pm & + \\
\hline 7 & + & + & - & + & - & \pm & + \\
\hline 8 & + & + & \pm & + & \pm & + & + \\
\hline 9 & \pm & + & \pm & + & \pm & + & + \\
\hline 10 & + & + & \pm & + & + & + & + \\
\hline 11 & + & + & \pm & + & + & \pm & + \\
\hline 12 & + & + & \pm & + & + & + & + \\
\hline 13 & + & \pm & - & + & + & \pm & + \\
\hline 14 & + & \pm & - & + & \pm & \pm & + \\
\hline 15 & + & \pm & - & + & \pm & + & + \\
\hline 16 & + & \pm & \pm & + & + & \pm & + \\
\hline 17 & + & + & - & + & + & + & + \\
\hline 18 & + & + & + & + & + & \pm & + \\
\hline
\end{tabular}

«+» positive, «-» negative, « $\pm »$ variable sign

In this study, the repetitive sequence-based (rep-PCR) technique was successfully applied for the comparative identification of the 18 different bacterial strains. The molecular typing consisted of 5 to 9 fingerprint bands ranging in size from $0.2 \mathrm{~Kb}$ to 1.4 $\mathrm{Kb}$. Several distinct polymorphic bands were observed for all of the bacterial strains, and the results are presented in Fig. 4.

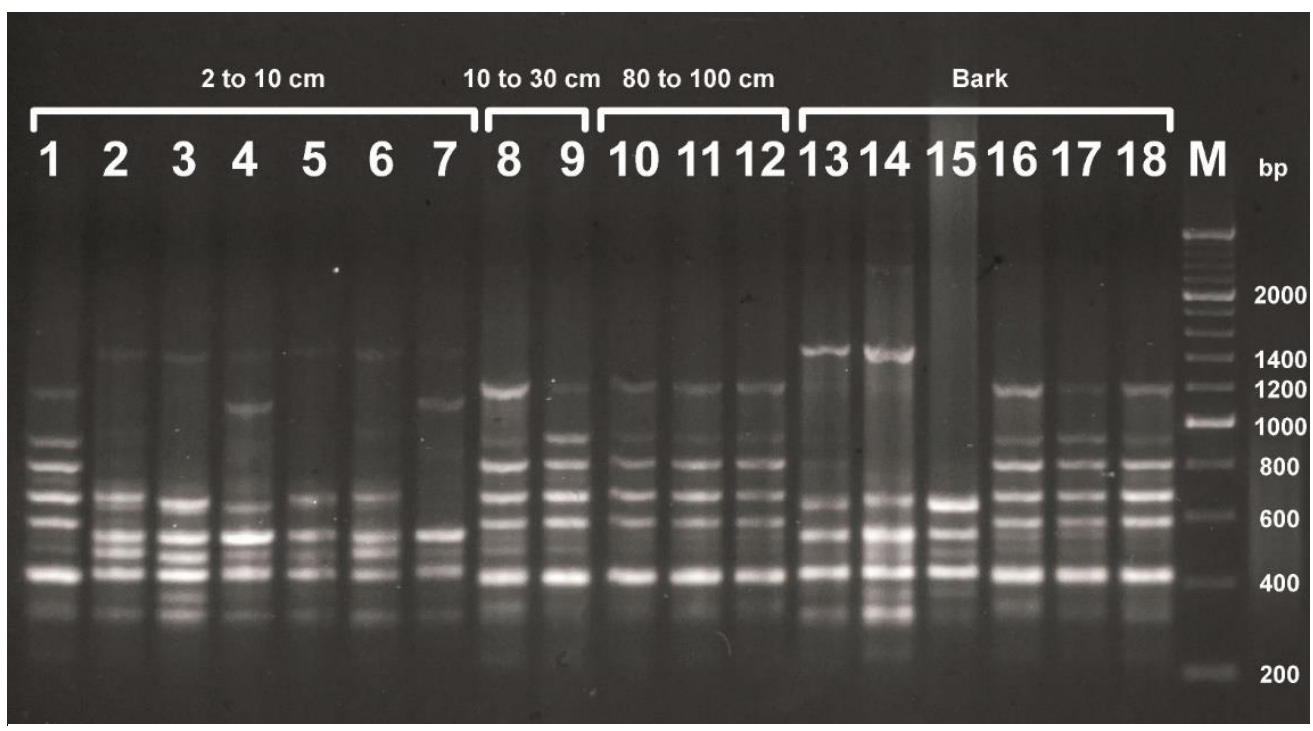

Fig. 4. PCR amplification of (GTG) 5 DNA fingerprinting (lanes 1 to 18 represent bacterial strains, lane $\mathrm{M}$ is $200 \mathrm{bp}$ DNA Ladder)

The (GTG) 5 band pattern revealed similar genetic fingerprints for all four sampling points. A $100 \%$ match of profiles was detected within several groups (sampling points of 
10 to $30 \mathrm{~cm}$ and 80 to $100 \mathrm{~cm}$ ). The above procedure gave a rough estimate, based on the sampling locations, of genetic similarity among the bacterial strains.

The species identification of the bacterial strains was conducted by the 16S rRNA sequence analysis, a standard technique in bacterial taxonomy. It is also commonly used in the 'polyphasic approach,' when new descriptions of microbial species, or higher taxa, are written (Ludwig and Schleifer 1999). There are some limitations when comparing the 16S rRNA gene sequences of phylogenetically homogeneous bacterial groups because the structurally conserved sequences found in the $16 \mathrm{~S}$ rRNA gene might not allow strains to identify up to the species level in closely related microorganisms. Moreover, it was assumed that species with $70 \%$ or greater DNA similarity usually have more than $97 \%$ sequence identity. This made it possible, with a high probability, to relate the isolated strains to thermophilic bacteria. As a result of the 16S rRNA gene sequencing, the isolated strains were identified as Parageobacillus caldoxylosilyticus and Parageobacillus thermoglucosidasius. Phylogenetic tree illustrating the evolutionary history of bacteria is presented in Fig.5.

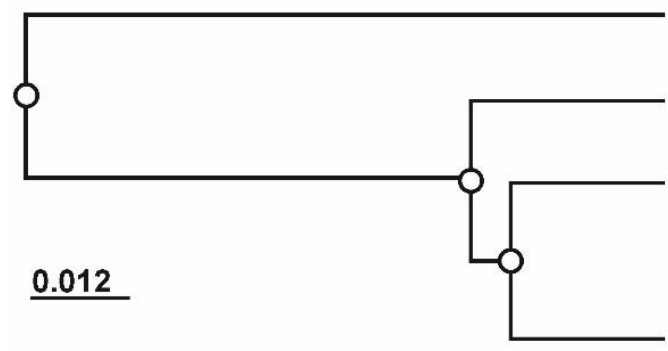

\section{Bacillus subtilis \\ Parageobacillus caldoxylosilyticus \\ Parageobacillus thermoglucosidans \\ Geobacillus thermodenitrificans}

Fig. 5. Phylogenetic tree illustrating the evolutionary history of bacteria, constructed using the maximum composite likelihood function (evolutionary history) and neighbor-joining method within the program MEGA

The abovementioned genus of Parageobacillus was classified as a Geobacillus genus, isolated from petroleum reservoir formation waters and first described back in 2001 (Nazina et al. 2001). Fifteen years later the Geobacillus genus was re-assessed and divided into the genus of two separate genera, Geobacillus and Parageobacillus, differing in terms of their nucleotide base compositions (Aliyu et al. 2016). Today, the Parageobacillus species and their secretome remain largely unexplored. The few available studies suggest possible use of the species in bioethanol and hydrogen production (Bibra et al. 2017; Mohr et al. 2018). The bacterial strains were also reported to produce mixtures of organic acids, proteins, enzymes, and toxins (Bibra et al. 2017; Lebre et al. 2018).

The 18 isolated bacterial strains were examined with respect to their amylase activity on agar plates with the addition of $1 \%$ starch. The formation of clearing zones around each colony indicated the presence of amylase activity as a characteristic feature of all the studied strains (Fig. 6). The maximum amylase activity was observed in strains 15, 16 , and 18, which had been isolated from the bark layer of the woody-chip pile. A possible explanation could be that the processed trees were obtained in the period from July to October, when most of the starch accumulates in the tissues of the bark (Yoshioka et al. 1988).

Testing the xylanase activity was another important task performed with the aim of defining the most promising producers of xylanolitic enzymes. A quantitative comparison was conducted for the enzyme complexes isolated from culture fluids of the strains. The values were calculated based on the initial rates of xylan hydrolysis. 


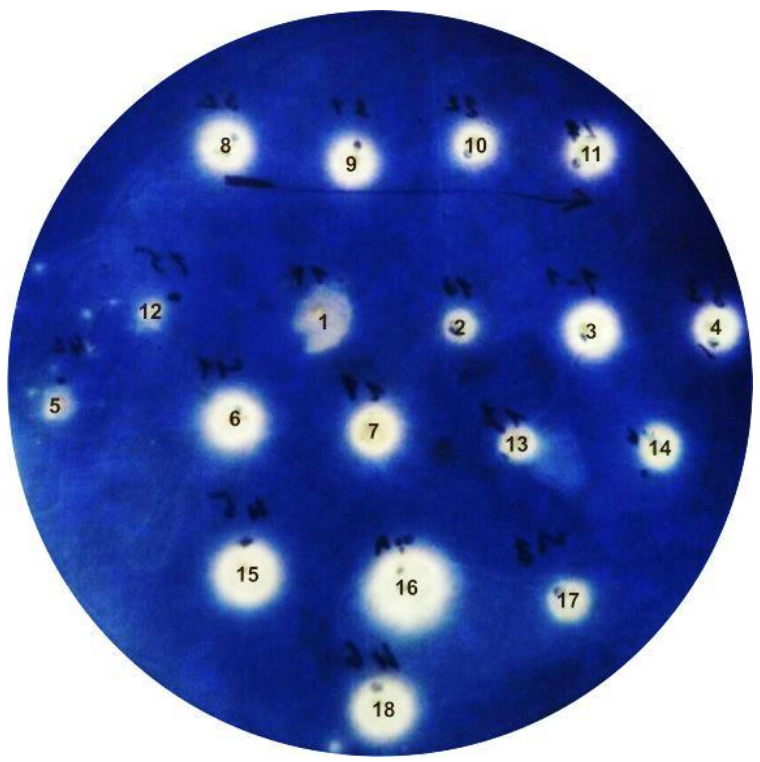

Fig. 6. The photograph of 18 bacterial strains subjected to the amylase activity tests

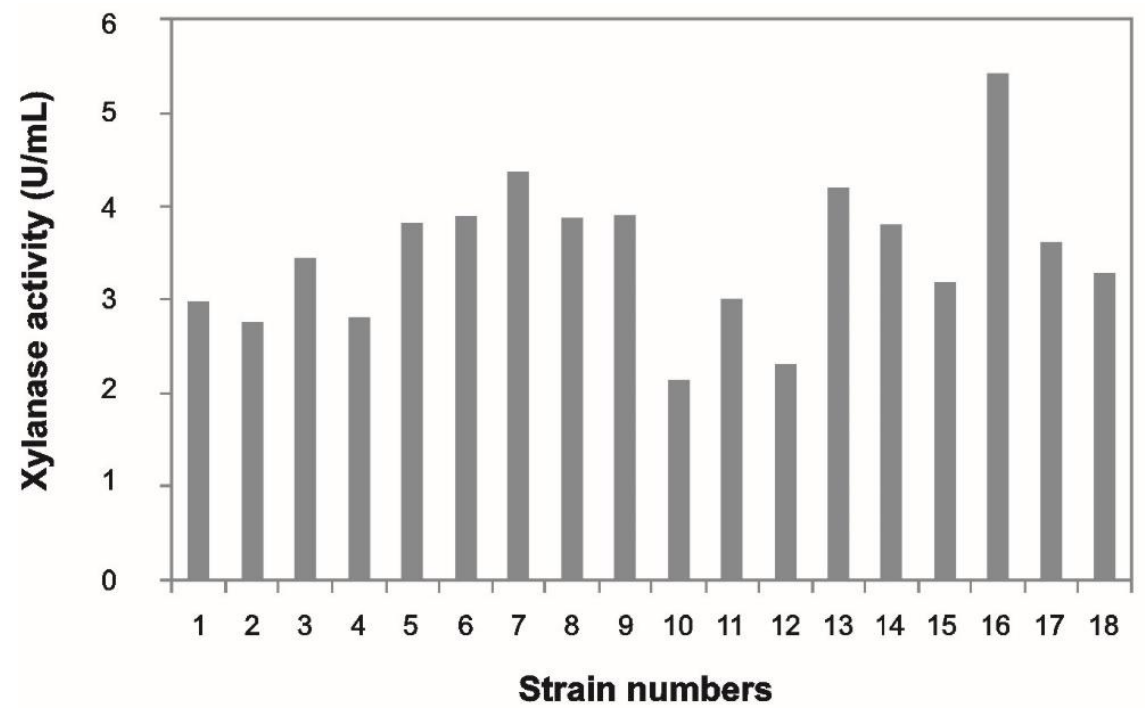

Fig. 7. Xylanase activities of 18 bacterial strains

Figure 7 shows that all of the isolates were xylanase positive and xylanase activity ranged from 2.1 to $5.4 \mathrm{U} / \mathrm{mL}$. Strains 7 and 16 showed the highest values of xylanase activity and were selected for further experiments. It should be mentioned that the extracellular activity levels in all the 18 strains were quite low compared to other strains reported in the literature (Bibi et al. 2014; Thebti et al. 2016). This could have been due to characteristics of the habitat, where secretion of the extracellular enzymes in large quantities can be too energy consuming for a microorganism. It was concluded that practical utilization of the $P$. caldoxylosilyticus and $P$. thermoglucosidasius strains for xylanase production will require genetic improvement including the removal of genes responsible for the release of undesirable compounds.

The substrate specificity experiments were performed using birch chips, brewers' spent grain, and oat spelt xylan. The activities of the xylanases synthesized by $P$. caldoxylosilyticus and $P$. thermoglucosidasius were compared depending on the substrate 
origin. The bacteria were grown in a culture medium containing each substrate for $24 \mathrm{~h}$ at $60{ }^{\circ} \mathrm{C}$. It was determined that all of the selected substrates were capable of supporting bacterial growth accompanied by the production of xylanases. The results are presented in Fig. 8. The birch chips and brewers' spent grain were the best carbon sources for xylanase synthesis by $P$. thermoglucosidasius (PT), attaining $7.23 \mathrm{U} / \mathrm{mL}$ and $6.25 \mathrm{U} / \mathrm{mL}$, respectively. The maximum xylanase activity secreted by $P$. caldoxylosilyticus (PC) was achieved in the medium containing brewers' spent grain $(4.15 \mathrm{U} / \mathrm{mL})$. It was followed by oat spelt xylan $(3.90 \mathrm{U} / \mathrm{mL})$ and birch chips $(2.91 \mathrm{U} / \mathrm{mL})$. The variation in xylanase activity, depending on the type of substrate, may have been due to the fact that the materials contain xylan of different compositions. As a result, the bacterial strains synthesize xylanases specifically for a particular kind of bond. It can also be that the carbon substrates contain lignin, which is capable of inhibiting the activity of xylanases (Berlin et al. 2006).

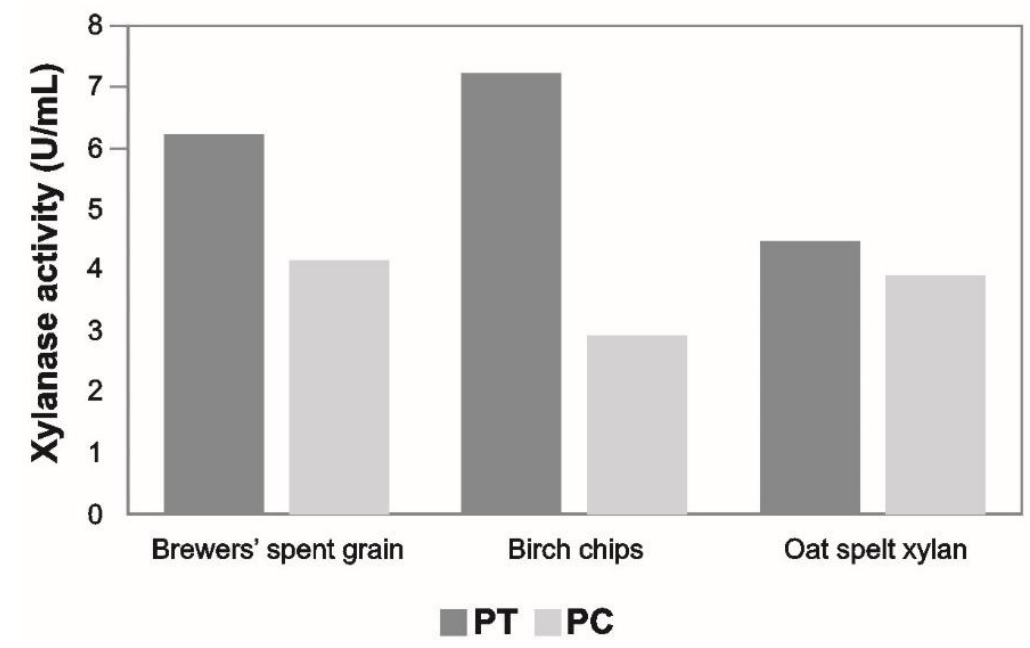

Fig. 8. The effect of carbon substrates on the xylanase activity of PC and PT strains

Bacteria live in and adapt to a wide diversity of environmental conditions. Certain factors can promote growth, while others will slow it down. Determination of the optimal growth conditions for the bacterial strains is an important step in achieving the best possible bacterial performance. The effects of temperature and $\mathrm{pH}$ on the growth of the two chosen bacterial strains are shown in Figs. 9 and 10.

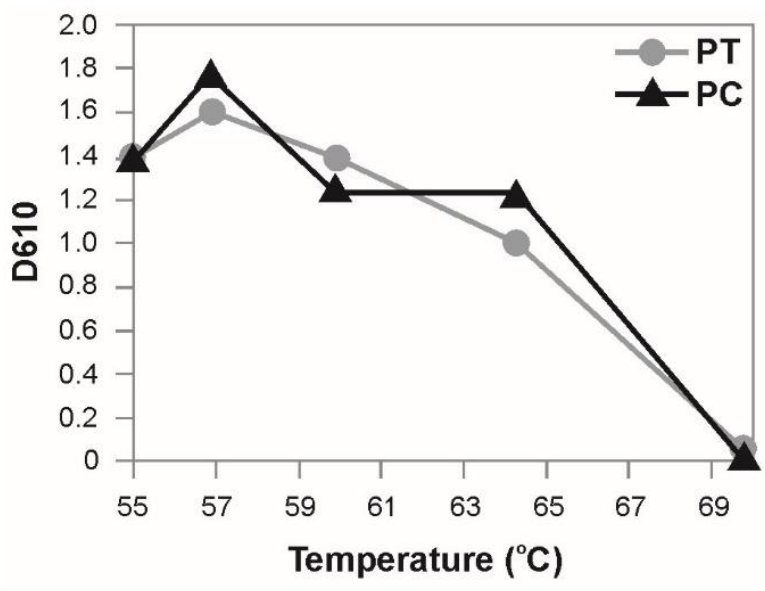

Fig. 9. The effect of temperature on the growth of PC and PT

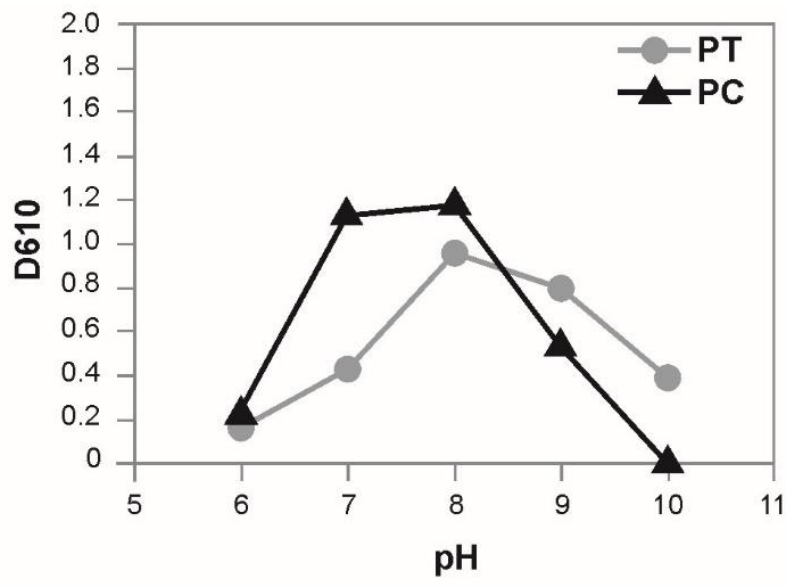

Fig.10. The effect of growth medium $\mathrm{pH}$ on the growth of PC and PT 
The values were plotted against the optical density measured at a wavelength of $610 \mathrm{~nm}$. The optimal temperature and $\mathrm{pH}$ for the growth of the $P$. thermoglucosidasius was established as 57 to $60^{\circ} \mathrm{C}$ and 8.5 , respectively. The optimal temperature and $\mathrm{pH}$ for the growth of the $P$. caldoxylosilyticus was 57 to $60{ }^{\circ} \mathrm{C}$ and 7 , respectively. The bacterial growth slowed down at temperatures below $55^{\circ} \mathrm{C}$ and above $70{ }^{\circ} \mathrm{C}$, as well as at a $\mathrm{pH}$ below 7 and above 8 . This indicated that the bacteria can be identified as moderate thermophiles and neutrophils and can potentially serve as a source of thermostable and alkaline enzymes.

\section{CONCLUSIONS}

1. Thermophilic bacteria from different layers of a woody-chip pile were isolated. A total of 18 bacterial strains were isolated, identified, and characterized.

2. Preliminary activity tests revealed that all 18 strains were capable of producing both amylases and xylanases.

3. The strains 7 and 16 found in the bark layer of the woody pile showed the highest xylanase activity $(4.4$ and $5.4 \mathrm{U} / \mathrm{mL})$ and were studied in detail. It was established that those strains were moderate thermophiles and neutrophils with a temperature and $\mathrm{pH}$ optimum ranging from 57 to $60^{\circ} \mathrm{C}$ and 7.0 to 8.5 , respectively.

4. The study also evaluated the effect of various carbon substrates on the xylanase activity. It has been shown that the birch chips and brewers' spent grain have potential to be economically viable carbon substrates for xylanase production by $P$. thermoglucosidasius and $P$. caldoxylosilyticus bacterial strains.

\section{ACKNOWLEDGEMENTS}

This work was supported by a grant from the Russian Ministry of Science and Higher Education (Project No. 15.8815.2017/8.9, Northern (Arctic) Federal University). The authors are thankful to Dmitry G. Chukhchin for the valuable assistance with SEM. The work was performed using instrumentation of the Core Facility Center "Arktika" at the Northern (Arctic) Federal University (Arkhangelsk, Russia).

\section{REFERENCES CITED}

Aliyu, H., Lebre, P., Blom, J., Cowan, D., and De Maayer, P. (2016). "Phylogenomic reassessment of the thermophilic genus Geobacillus," Syst. Appl. Microbiol. 39(8), 527-533. DOI: 10.1016/j.syapm.2016.09.004

Alves, L., Ladeira, S. A., and Paixão, S. M. (2016). "Characterization of thermophile xylanase produced by Anoxybacillus sp. strain 3M in submerged fermentation using brewers' spent grain," Curr. Biochem. Eng. 3(2), 74-81. DOI: $10.2174 / 2212711902666150519233412$

Behera, B. C., Sethi, B. K., Mishra, R. R., Dutta, S. K., and Thatoi, H. N. (2017). "Microbial cellulases - Diversity \& biotechnology with reference to mangrove environment: 
A review," J. Genet. Engin. Biotech. 15(1), 197-210. DOI:

10.1016/j.jgeb.2016.12.001

Berlin, A., Balakshin, M., Gilkes, N., Kadla, J., Maximenko, V., Kubo, S., and Saddler, J. (2006). "Inhibition of cellulase, xylanase, and beta-glucosidase activities by softwood lignin preparations," J. Biotechnol. 125(2), 198-209. DOI:

10.1016/j.jbiotec.2006.02.021

Bhalla, A., Bischoff, K., and Sani, R. (2015). "Highly thermostable xylanase production from a thermophilic Geobacillus sp. strain WSUCF1 utilizing lignocellulosic biomass," Front. Bioeng. Biotechnol. 3(84), 1-8. DOI: 10.3389/fbioe.2015.00084

Bibra, M., David, A., Johnson, G., and Sani, R. K. (2017). "Use Parageobacillus thermoglucosidasius: Save the planet," in: AIChE Annual Meeting, Minneapolis, MN, USA, pp. 35-36.

Bibi, Z., Ansari, A., Zohra, R. R., Aman, S., and Qader, S. A. U. (2014). "Production of xylan degrading endo-1, 4- $\beta$-xylanase from thermophilic Geobacillus stearothermophilus KIBGE-IB29," J. Radiat. Res. Appl. Sci. 7(4), 478-485. DOI: 10.1016/j.jrras.2014.08.001

Blamey, J. M., Fisher, F., Meyer, H.-P., Sarmiento, F., and Zinn, M. (2017). "Enzymatic biocatalysis in chemical transformations: A promising and emerging field in green chemistry practice," in: Biotechnology of Microbial Enzymes. Production, Biocatalysis, and Industrial Applications, G. Brahmachari, A. L. Demain, and J. L. Adrio (eds), Academic Press, New York, NY, USA, pp. 347-403. DOI: 10.1016/b978-0-12-803725-6.00014-5

Cai, H., Shi, P., Huang, H., Yuan, T., Yang, P., Luo, H., Meng, K., Bai, Y., and Yao, B. (2011). "A novel thermoacidophilic family 10 xylanase from Penicillium pinophilum C1," Process Biochem. 46(12), 2341-2346. DOI: 10.1016/j.procbio.2011.09.018

Choi, J.-M., Han, S.-S., and Kim, H.-S. (2015). "Industrial applications of enzyme biocatalysis: Current status and future aspect," Biotechnol. Adv. 33(7), 1443-1454. DOI: $10.1016 /$ j.biotechadv.2015.02.014

Coughlan, M. P. (1985). "The properties of fungal and bacterial cellulases with comment on their production and application," Biotechnol. Genet. Eng. 3(1), 39-110. DOI: 10.1080/02648725.1985.10647809

Daas, M., Van de Weijer, A., De Vos, W. M., and Van der Oost, J. (2016). "Isolation of a genetically accessible thermophilic xylan degrading bacterium from compost," Biotechnol. Biofuels 9(1), 1-13. DOI: 10.1186/s13068-016-0618-7

Gopinath, S. C. B., Anbu, P., Md Arshad, M. K., Lakshmipriya, T., Hong Voon, C., Hashim, U., and Chinni, S. V. (2017). "Biotechnological processes in microbial amylase production," BioMed Res. Int. 2017, Article ID 1272193. DOI: $10.1155 / 2017 / 1272193$

Handelsman, J. (2004). "Metagenomics: Application of genomics to uncultured microorganisms," Microbiol. Mol. Biol. R. 68(4), 669-685. DOI: 10.1128/MMBR.68.4.669-685.2004

Hardiman, E., Gibbs, M., Reeves, R., and Bergquist, P. (2010). "Directed evolution of a thermophilic beta-glucosidase for cellulosic bioethanol production," Appl. Biochem. Biotech. 161(1-8), 301-312. DOI: 10.1007/s12010-009-8794-6

Hu, J., Chandra, R., Arantes, V., Gourlay, K., and Van Dyk, J. S., Saddler, J. N. (2015). "The addition of accessory enzymes enhances the hydrolytic performance of cellulase enzymes at high solid loadings," Bioresource Technol. 186, 149-153. DOI: 10.1016/j.biortech.2015.03.055 
Jemli, S., Avadi-Zouari, D., Hlima, H. B., and Bejar, S. (2016). "Biocatalysts: Application and engineering for industrial purposes," Crit. Rev. Biotechnol. 36(2), 246-258. DOI: 10.3109/07388551.2014.950550

Kathleen, M. M., Samuel, L., Felecia, C., Ng, K. H., Leslie, M. B., and Kasing, A. (2014). "(GTG)5-PCR analysis and 16S rRNA sequencing of bacteria from Sarawak aquaculture environment," Int. Food Res. J. 21(3), 915-920.

Kumar, V., Verma, D., Archana, A., and Satyanarayana, T. (2013). "Thermostable bacterial xylanases," in: Thermophilic Microbes in Environmental and Industrial Biotechnology: Biotechnology of Thermophiles, Second Edition, T. Satyanarayana, J. Littlechild, and Y. Kawarabayasi (eds.), Springer Dordrecht, Berlin-Heidelberg, Germany, pp. 813-857.

Larsen, K. L., and McCartney, D. M. (2000). "Effect of C:N ratio on microbial activity and N retention: Bench-scale study using pulp and paper biosolids," Compost Sci. Util. 8(2), 147-159. DOI: 10.1080/1065657X.2000.10701760

Lebre, P. H., Aliyu, H., De Maayer, P., and Cowan, D. A. (2018). "In silico characterization of the global Geobacillus and Parageobacillus secretome," Microb. Cell Fact. 17, 156-174. DOI: 10.1186/s12934-018-1005-9

Ludwig, W., and Schleifer, K. H. (1999). "Phylogeny of bacteria beyond the 16S rRNA standard," ASM News 65(11), 752-757.

Madhavan, A., Sindhu, R., Binod, P., Sukumaran, R. K., and Pandey, A. (2017). "Strategies for design of improved biocatalysts for industrial applications," Bioresource Technol. 245, 1304-1313. DOI: 10.1016/j.biortech.2017.05.031

Mohr, T., Aliyu, H., Küchlin, R., Polliack, S., Zwick, M., Neumann, A., Cowan, D., and De Maayer, P. (2018). "CO-dependent hydrogen production by the facultative anaerobe Parageobacillus thermoglucosidasius," Microb. Cell Fact. 17, 108-119. DOI: 10.1186/s12934-018-0954-3

Nazina, T. N., Tourova, T. P., Poltaraus, A. B., Novikova, E. V., Grigoryan, A. A., Ivanova, A. E., Lysenko, A. M., Petrunyaka, V. V., Osipov, G. A., Belyaev, S. S., et al. (2001). "Taxonomic study of aerobic thermophilic bacilli: Descriptions of Geobacillus subterraneus gen. nov., sp. nov. and Geobacillus uzenensis sp. nov. from petroleum reservoirs and transfer of Bacillus stearothermophilus, Bacillus thermocatenulatus, Bacillus thermoleovorans, Bacillus kaustophilus, Bacillus thermoglucosidasius and Bacillus thermodenitrificans to Geobacillus as the new combinations $G$. stearothermophilus, G. thermocatenulatus, G. thermoleovorans, G. kaustophilus, G. thermoglucosidasius and G. thermodenitrificans," Int. J. of Syst. Evol. Micr. 51(pt 2), 433-446. DOI: 10.1099/00207713-51-2-433

Nigam, P. S. N., and Pandey, A. (2009). Biotechnology for Agro-Industrial Residues Utilisation, Springer Dordrecht, Heidelberg, Germany. DOI: 10.1007/978-1-40209942-7

Nigam, P., and Singh, D. (1995). "Enzyme and microbial systems involved in starch processing," Enzyme Microb. Tech. 17(9), 770-778. DOI: 10.1016/01410229(94)00003-A

Pandey, A., Nigam, P., Soccol, C. R., Soccol, V. T., Singh, D., and Mohan, R. (2000). "Advances in microbial amylases," Biotechnol. Appl. Bioc. 31(Part 2), 135-152. DOI: 10.1042/BA19990073

Polizeli, M. L., Rizzatti, A. C., Monti, R., Terenzi, H. F., Jorge, J. A., and Amorim, D. S. (2005). "Xylanases from fungi: Properties and industrial applications," Appl. Microbiol. Biot. 67(5), 577-591. DOI: 10.1007/s00253-005-1904-7 
Rasschaert, G., Houf, K., Imberechts, H., Grijspeerdt, K., De Zutter, L., and Heyndrickx, M. (2005). "Comparison of five repetitive-sequence-based PCR typing methods for molecular discrimination of Salmonella enterica isolates," J. Clin. Microbiol. 43(8), 3615-3623. DOI: 10.1128/JCM.43.8.3615-3623.2005

Raul, D., Biswas, T., Mukhopadhyay, S., Das, S. K., and Gupta, S. (2014). "Production and partial purification of alpha amylase from Bacillus subtilis (MTCC 121) using solid state fermentation," Biochem. Res. Int. 2014, Article ID 568141. DOI: $10.1155 / 2014 / 568141$

Renneberg, J., Rieneck, K., and Gutschik, E. (1995). "Evaluation of Staph ID 32 system and Staph-Zym system for identification of coagulase-negative staphylococci," $J$. Clin. Microbiol. 33(5), 1150-1153.

Saxena, A., and Singh Chauhan, P. (2016). "Role of various enzymes for deinking paper: A review," Crit. Rev. Biotechnol. 37(5), 598-612. DOI: 10.1080/07388551.2016.1207594

Sinelnikov, I., Yunitsyna, O., Rudakov, I., and Emelyanova, M. (2017). "Isolation of thermophilic xylanolitic bacteria from woody-chip pile," in: $17^{\text {th }}$ International Multidisciplinary Scientific GeoConference SGEM 2017, Vienna, Austria, pp. 273280. DOI: $10.5593 /$ sgem2017H/63/S25.035

Sinitsyna, O. A., Bukhtoyarov, F. E., Gusakov, A. V., Okunev, O. N., Vinetsky, Y. P., Bekkarevitch, A. O., and Sinitsyn, A. P. (2003). "Isolation and properties of major components of Penicillium canescens extracellular enzyme complex," Biochemistry (Moscow) 68(11), 1200-1209.

Streit, W. R., Daniel, R., and Jaeger, K. E. (2004). "Prospecting for biocatalysts and drugs in the genomes of non-cultured microorganisms," Curr. Opin. Biotech. 15(4), 285-290. DOI: 10.1016/j.copbio.2004.05.006

Teodoro, C. S., and Martins, M. (2000). "Culture conditions for the production of thermostable amylase by Bacillus sp.," Braz. J. Microbiol. 31, 289-302. DOI: 10.1590/s1517-83822000000400011

Thebti, W., Riahi, Y., Gharsalli, R., and Belhadj, O. (2016). "Screening and characterization of thermo-active enzymes of biotechnological interest produced by thermophilic Bacillus isolated from hot springs in Tunisia," Acta Biochim. Pol. 63(3), 581-587. DOI: 10.18388/abp.2016_1271

Valladares Juárez, A. G., Dreyer, J., Göpel, P. K., Koschke, N., Frank, D., Märkl, H., and Müller, R. (2009). "Characterisation of a new thermoalkaliphilic bacterium for the production of high-quality hemp fibres, Geobacillus thermoglucosidasius strain PB94A," Appl. Microbiol. Biot. 83(3), 521-527. DOI: 10.1007/s00253-009-1969-9

Viikari, L., Kantelinen, A., Sundquist, J., and Linko, M. (1994). "Xylanases in bleaching: From an idea to the industry," FEMS Microbiol. Rev. 13(2-3), 335-350. DOI: 10.1111/j.1574-6976.1994.tb00053.x

Yoshioka, H., Nagai, K., Aoba, K., and Fukumoto, M. (1988). "Seasonal changes of carbohydrates metabolism in apple trees," Sci. Hortic.-Amsterdam 36(3-4), 219-227. DOI: $10.1016 / 0304-4238(88) 90056-8$

Article submitted October 25, 2018; Peer review completed: December 15, 2018; Revised version received: December 26, 2018; Accepted: December 28, 2018; Published: January 8, 2019.

DOI: 10.15376/biores.14.1.1452-1465 